J. Dairy Sci. 96:7371-7381

http://dx.doi.org/10.3168/jds.2013-7084

(C) American Dairy Science Association ${ }^{\circledR}, 2013$.

\title{
Variation in nutrients formulated and nutrients supplied on 5 California dairies
}

\author{
H. A. Rossow* ${ }^{1}$ and S. S. Aly* $\dagger$ \\ *Veterinary Medicine Teaching and Research Center, School of Veterinary Medicine, University of California, Davis, 18830 Road 112 , \\ Tulare 93274 \\ †Department of Population Health and Reproduction, School of Veterinary Medicine, University of California, Davis, One Shields Avenue, \\ CA 95616
}

\begin{abstract}
Computer models used in ration formulation assume that nutrients supplied by a ration formulation are the same as the nutrients presented in front of the cow in the final ration. Deviations in nutrients due to feed management effects such as dry matter changes (i.e., rain), loading, mixing, and delivery errors are assumed to not affect delivery of nutrients to the cow and her resulting milk production. To estimate how feed management affects nutrients supplied to the cow and milk production, and determine if nutrients can serve as indexes of feed management practices, weekly total mixed ration samples were collected and analyzed for 4 pens (close-up cows, fresh cows, high-milk-producing, and low-milk-producing cows, if available) for 7 to 12 wk on 5 commercial California dairies. Differences among nutrient analyses from these samples and nutrients from the formulated rations were analyzed by PROC MIXED of SAS (SAS Institute Inc., Cary, NC). Milk fat and milk protein percentages did not vary as much [coefficient of variation $(\mathrm{CV})=18$ to $33 \%$ ] as milk yield (kg; CV $=16$ to $47 \%$ ) across all dairies and pens. Variability in nutrients delivered were highest for macronutrient fat $(\mathrm{CV}=22 \%)$, lignin $(\mathrm{CV}=15 \%)$, and ash $(\mathrm{CV}=11 \%)$ percentages and micronutrients $\mathrm{Fe}(\mathrm{mg} / \mathrm{kg} ; \mathrm{CV}=48 \%), \mathrm{Na}(\% ; \mathrm{CV}=42 \%)$, and $\mathrm{Zn}$ $(\mathrm{mg} / \mathrm{kg} ; \mathrm{CV}=38 \%)$ for the milking pens across all dairies. Partitioning of the variability in random effects of nutrients delivered and intraclass correlation coefficients showed that variability in lignin percentage of TMR had the highest correlation with variability in milk yield and milk fat percentage, followed by fat and crude protein percentages. But, variability in ash, fat, and lignin percentages of total mixed ration had the highest correlation with variability in milk protein percentage. Therefore, lignin, fat, and ash may be the best indices of feed management to include effects of
\end{abstract}

Received May 30, 2013.

Accepted July 22, 2013.

${ }^{1}$ Corresponding author: Heidi.Rossow@gmail.com variability in nutrients on variability in milk yield, milk fat, and milk protein percentages in ration formulation models.

Key words: nutrient variability, ration formulation variability, milk production variability

\section{INTRODUCTION}

How much effect nutrient variability has on variability in milk production is unknown. But, it is known that increasing nutrient variability decreases milk production (Friggens et al. 1995; Stone, 2008; Weiss et al., 2012). It is generally accepted that at least 5 rations are possible on a dairy. The first is the ration that is formulated to meet the cow or pen requirements; the second is the ration that is entered into the feed management software, complete with current DM values; the third is the ration that is loaded into the feed wagon; the fourth is the ration that is delivered to the cows; and the fifth is the ration that the cows eat. At each stage of creating the final ration, variation in nutrient content of the ration will increase and be affected by feed management (Kertz, 1998). The computer diet may be altered to reflect current feed prices and inventory without reformulation, DM contents may not be up to date with current weather and storage conditions, feed wagon or loader weigh cells may not be calibrated correctly, feed wagons may not be well maintained, and errors associated with weighing, mixing feed ingredients, and unloading rations will affect the supply of nutrients delivered to cows. Cows will sort feed ingredients and ingredient intake will be affected by the order in which the cows approach the feed bunk. Endres and Espejo (2010) described the interaction among feeding management and ration characteristics and compared DM, NDF, and CP content of the analyzed ration to the formulated ration from bunk samples. They found an association between changes in NDF content over time (due to sorting) and low milk production, which was probably due to herds with poorer feed management, indicating that variability in NDF could contribute to decreased milk production 
but it could also be confounded with herds with higher NDF in the TMR. Huzzey et al. (2013) examined the effect of variation in energy density in TMR on feeding behavior of dairy heifers and determined that increased variation in energy density across the feed bunk and across days changed the eating behavior of the heifers and increased changes in feeding locations and competitive behavior at the feed bunk, also increasing variability in performance. Variability in nutrient content of the ration affects performance and consistency of nutrients supplied to the cows and is a direct reflection of feed management practices. Therefore, variability in individual nutrients may serve as a useful index of the effect of feed management practices on nutrients supplied to dairy cows that can be included in ration formulation.

Current models and ration formulation packages do not take feed management factors into consideration in ration formulation (Sniffen et al., 1993; Bach et al., 2008). Models predict nutrient requirements of an individual cow without consideration of variability among cows within a pen or variation due to feed management (Pecsok et al., 1992). In addition, feed libraries associated with ration formulation packages will also affect nutrient content of the rations, as feed ingredients that are not routinely analyzed (i.e., book values) may not be representative of local feed ingredient nutrient compositions (Sniffen et al., 1993; Kertz, 1998; Endres and Espejo, 2010). How dairy cattle are fed, quality control of feeds, feed mixing, and loss of feed sources due to spoilage, loading, weather, and so on, affect the health and production of dairy cattle and profitability of a dairy (Sniffen et al., 1993; Bach et al., 2008). The purpose of the current research was to quantify the relationship between variation in milk production and TMR nutrient variation to examine its use as an index of feed management for ration formulation. Therefore, the objectives of this research were to (1) quantify variability in TMR nutrients supplied to and milk produced by cows for each dairy, (2) compare variability among TMR nutrients from the nutritionist formulation, laboratory analyses, and nutrients calculated from TMR ingredients loaded into the mixer wagon using the NRC $(1989,2001)$ guidelines or the nutritionist feed library within the ration formulation program to determine the importance of using laboratory analyses to evaluate rations, and (3) identify which nutrient variability increases variability in milk production, thus possibly serving as an index of feed management.

\section{MATERIALS AND METHODS}

Data from 5 commercial dairies located in Tulare and Kings Counties (California) was used in this study and are described in Tables 1 and 2. All dairies have feed management software: either EZfeed (DHI-Provo, Provo, UT) or FeedWatch (Valley Ag Software, Tulare, CA). Total mixed ration samples, feed management data, and milk production data were collected from 4 pens at each dairy, representing close-up cows (3 wk or less before calving), fresh cows (3 to 30 DIM), highproducing cows (30 to $150 \mathrm{DIM}$ ), and if possible, lowproducing cows ( $>150$ DIM) in fall 2010 and summer 2011. Therefore, pen is considered the experimental unit of interest. Monthly milk test data was downloaded from DHI-Plus software (DHI-Provo) or DairyCOMP software (Valley Ag Software) for at least 2 test days during the time of TMR sample collection. Dairy 1 was sampled in 2010, dairies 2 and 3 were sampled in both years, and dairies 4 and 5 were sampled in 2011. Milk fat percentage and (or) milk protein percentage data were not available from dairy 4 and dairy 2 because these dairies do not include milk protein and milk fat in their DHIA testing. Therefore, they were excluded from

Table 1. Description of dairies ${ }^{1}$

\begin{tabular}{|c|c|c|c|c|c|}
\hline \multirow[b]{2}{*}{ Item } & \multicolumn{5}{|c|}{ Dairy } \\
\hline & 1 & 2 & 3 & 4 & 5 \\
\hline Facilities & Freestall & Dry lot & Freestall & Freestall & Dry lot \\
\hline Average DIM & $195(56)$ & $166(67)$ & $189(60)$ & $181(61)$ & $187(64)$ \\
\hline Herd milk yield (kg/cow per day) & $30(33)$ & $32(30)$ & $35(29)$ & $39(25)$ & $32(28)$ \\
\hline Herd protein $(\%)$ & $3.5(20)$ & & $3.1(12)$ & & $3.2(8.4)$ \\
\hline Herd fat (\%) & $3.1(11)$ & $3.6(18)$ & $3.6(23)$ & & $3.6(14)$ \\
\hline
\end{tabular}

${ }^{1}$ Means [CV (\%) in parentheses].

${ }^{2}$ FeedWatch (Valley Ag Software, Tulare, CA); EZfeed (DHI-Provo, Provo, UT). 
those statistical analyses, respectively. Ration ingredients delivered to the different pens can be found in the Appendix (Tables A1-A4).

The feeding process and associated errors are listed in Figure 1. Data associated with each step in the feeding process includes errors listed to the right. Although data were not collected specifically to quantify each error, these errors are included in estimates of nutrients supplied to the cows. A description of data collection and processing at each step with contributing errors in the feeding follows.

\section{Nutritionist Diet-Formulated TMR Nutrients and Ingredients}

Nutrient and ingredient profiles for all 4 pens at the 5 dairies were collected from the nutritionists and represented rations formulated using CPM Dairy (Cornell-Penn-Miner, version 3.0.1; published by Cornell University, Ithaca, NY; University of Pennsylvania, Philadelphia, PA; and Miner Institute, Chazy, NY) or AMTS (version 2.0.15; Agricultural Modeling and Training Systems LLC, Cortland, NY). Errors associated with this step in the feeding process include errors in data entry into the dairy feed management computer; errors in nutrient analysis or estimation in the feed ingredients, including errors in DM; and errors of prediction of nutrient requirements by the model and linear or nonlinear algorithm used in the ration formulation program. Formulated TMR nutrients from the nutritionist ration formulation programs are abbreviated as NUT.

\section{Loaded Diet-Estimated TMR Nutrients From Loaded Ingredients}

Back up files from EZfeed or FeedWatch feed management software programs were collected weekly and data representing daily as-fed weights of ingredients dumped into the mixer wagons on each day for each load fed to the pens were extracted from the backup files. As-fed values per pen were converted to DM values per head using daily DM values for ingredients and numbers of cows per pen recorded in the feed management software. Delivered TMR nutrients were estimated from delivered ingredients using the feed lists in the NRC (1989, 2001) guidelines and also from the ingredient library in the ration formulation package used by the nutritionists (CPM Dairy or AMTS), abbreviated as NRL. Errors associated with the loaded diet are errors in DM estimation within the feed management software, errors in overloading or underloading ingredients into the feed wagon by dairy employees, and, for NRCand NRL-estimated nutrients, errors associated with not performing laboratory analyses on each ingredient loaded into the feed wagon.

\section{Delivered Diet—Laboratory Analyses}

All dairies were sampled once per week for approximately 6 to $10 \mathrm{wk}$ according to Weiss et al. (2012) from 4 pens per dairy. Empty feed tubs (1-3) were placed in feed bunks just before the feed wagon dropped a load. Tubs (approximately 5 to $10 \mathrm{~kg}$ as-fed TMR per tub) were then collected and contents mixed on a clean large

Table 2. Descriptions of pens, including numbers of cows, means, and CV for DIM and milk production, which were sampled for each of the 5 dairies

\begin{tabular}{|c|c|c|c|c|c|c|c|c|c|c|}
\hline \multirow[b]{2}{*}{ Item } & \multicolumn{2}{|c|}{ Dairy 1} & \multicolumn{2}{|c|}{ Dairy 2} & \multicolumn{2}{|c|}{ Dairy 3} & \multicolumn{2}{|c|}{ Dairy 4} & \multicolumn{2}{|c|}{ Dairy 5} \\
\hline & Mean & $\mathrm{CV}(\%)$ & Mean & $\mathrm{CV}(\%)$ & Mean & $\mathrm{CV}(\%)$ & Mean & $\mathrm{CV}(\%)$ & Mean & $\mathrm{CV}(\%)$ \\
\hline Milk, fresh pen (kg/cow per day) & $36.9^{\mathrm{d}}$ & 19 & $28.6^{\mathrm{b}}$ & 41 & $30.4^{\mathrm{c}}$ & 30 & $25.5^{\mathrm{a}}$ & 47 & $28.9^{\mathrm{bc}}$ & 34 \\
\hline Milk protein, fresh pen $(\mathrm{kg})$ & $1.13^{\mathrm{a}}$ & 19 & & & $1.02^{\mathrm{a}}$ & 29 & & & $0.989^{\mathrm{a}}$ & 33 \\
\hline Milk fat, fresh pen $(\mathrm{kg})$ & $1.36^{\mathrm{bc}}$ & 25 & $1.11^{\mathrm{a}}$ & 45 & $1.28^{\mathrm{b}}$ & 31 & & & $1.22^{\mathrm{b}}$ & 33 \\
\hline Milk, high pen ( $\mathrm{kg} /$ cow per day) & $36.3^{\mathrm{a}}$ & 26 & $35.9^{\mathrm{a}}$ & 22 & $38.9^{\mathrm{b}}$ & 20 & $45.4^{\mathrm{c}}$ & 16 & $39.8^{\mathrm{b}}$ & 23 \\
\hline Milk protein, high pen $(\mathrm{kg})$ & $1.05^{\mathrm{a}}$ & 27 & & & $1.11^{\mathrm{a}}$ & 18 & & & $1.23^{\mathrm{b}}$ & 20 \\
\hline Milk fat, high pen (kg) & $1.09^{\mathrm{a}}$ & 30 & $1.25^{\mathrm{b}}$ & 26 & $1.31^{\mathrm{c}}$ & 24 & & & $1.39^{\mathrm{d}}$ & 24 \\
\hline Number of low cows ${ }^{2}$ & & & & & & & 1,117 & & 466 & \\
\hline DIM, low pen & & & & & & & $308^{\mathrm{b}}$ & 23 & $250^{\mathrm{a}}$ & 58 \\
\hline Milk, low pen ( $\mathrm{kg} / \mathrm{cow}$ per day) & & & & & & & $34.6^{\mathrm{a}}$ & 18 & $28.1^{\mathrm{b}}$ & 20 \\
\hline Milk protein, low pen $(\mathrm{kg})$ & & & & & & & & & 0.931 & 18 \\
\hline
\end{tabular}

\footnotetext{
${ }^{\mathrm{a}-\mathrm{d}}$ Means within a row with different superscripts are different at $P<0.01$.

${ }^{1}$ High cows are high-producing cows (21 DIM to approximately 200 DIM).

${ }^{2}$ Low cows are low-producing cows (200 DIM to nonlactating, dry).
} 


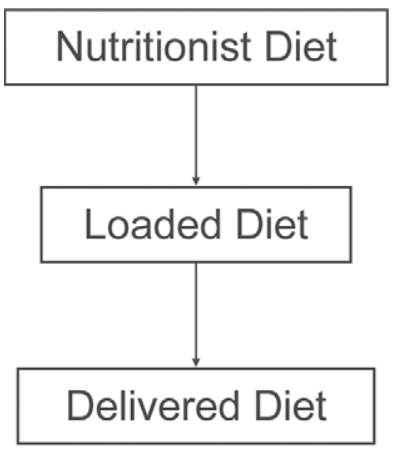

inductively coupled plasma-mass spectrophotometry (AOAC International, 1999; method 985.01 for Ca, P, $\mathrm{Mg}, \mathrm{K}, \mathrm{Na}, \mathrm{Fe}, \mathrm{Cu}, \mathrm{Mn}$, and Zn; method 923.01 for S; and method 915.01 for $\mathrm{Cl}$ ). Total mixed ration samples represented nutrients delivered to the pen and included errors associated with feed bunk sampling, laboratory analysis, and improper mixing and unloading the TMR in the bunk (unloading error).

\section{Lab - Analytical error - Sampling error - Unloading error}

Figure 1. Flowchart representing the feeding process on a dairy and potential errors in nutrients supplied to cows.

cement floor. The TMR pile was then quartered and opposite quarters were mixed and collected into a quart Ziploc bag for nutrient analyses by Analab (a division of Agri-King Inc., Fulton, IL). Nutrient values from these laboratory analyses are abbreviated as LAB. Samples were analyzed for DM, ADF, NDF, CP, fat, ash, and lignin using wet chemistry analyses (AOAC International, 1999; methods 935.29, 973.18, 2002.04, 990.03, $920.39,942.05,973.18$, respectively), starch using nearinfrared reflectance spectroscopy (based on predictive equations developed at Analab), and mineral analyses (Ca, P, Mg, K, S, Na, Cl, Fe, Cu, Mn, and Zn) using

\section{Statistics}

For objective 1 (to quantify variability in nutrients supplied to and milk produced by cows for each dairy and pen), laboratory nutrient analyses of feed bunk samples and DHIA milk records (Figure 2) were analyzed using the PROC UNIVARIATE of SAS (SAS Institute Inc., Cary, NC) for means and coefficients of variation. Then, using PROC MIXED of SAS, test-day milk production and DIM (Table 2) among dairies and pens were compared, nesting pen within dairy, with dairy as a random effect and cow as a repeated effect.

For objective 2 [to compare variability among ration nutrients from the nutritionist formulation to laboratory analyses and nutrients calculated from ingredients loaded into the mixer wagon to determine the importance of using laboratory analyses to evaluate rations (Table 3)], PROC MIXED of SAS was used to compare estimates of TMR nutrients, with dairy as a random

Table 3. Comparison of methods of estimation of TMR nutrient content for all dairies and pens ${ }^{1}$

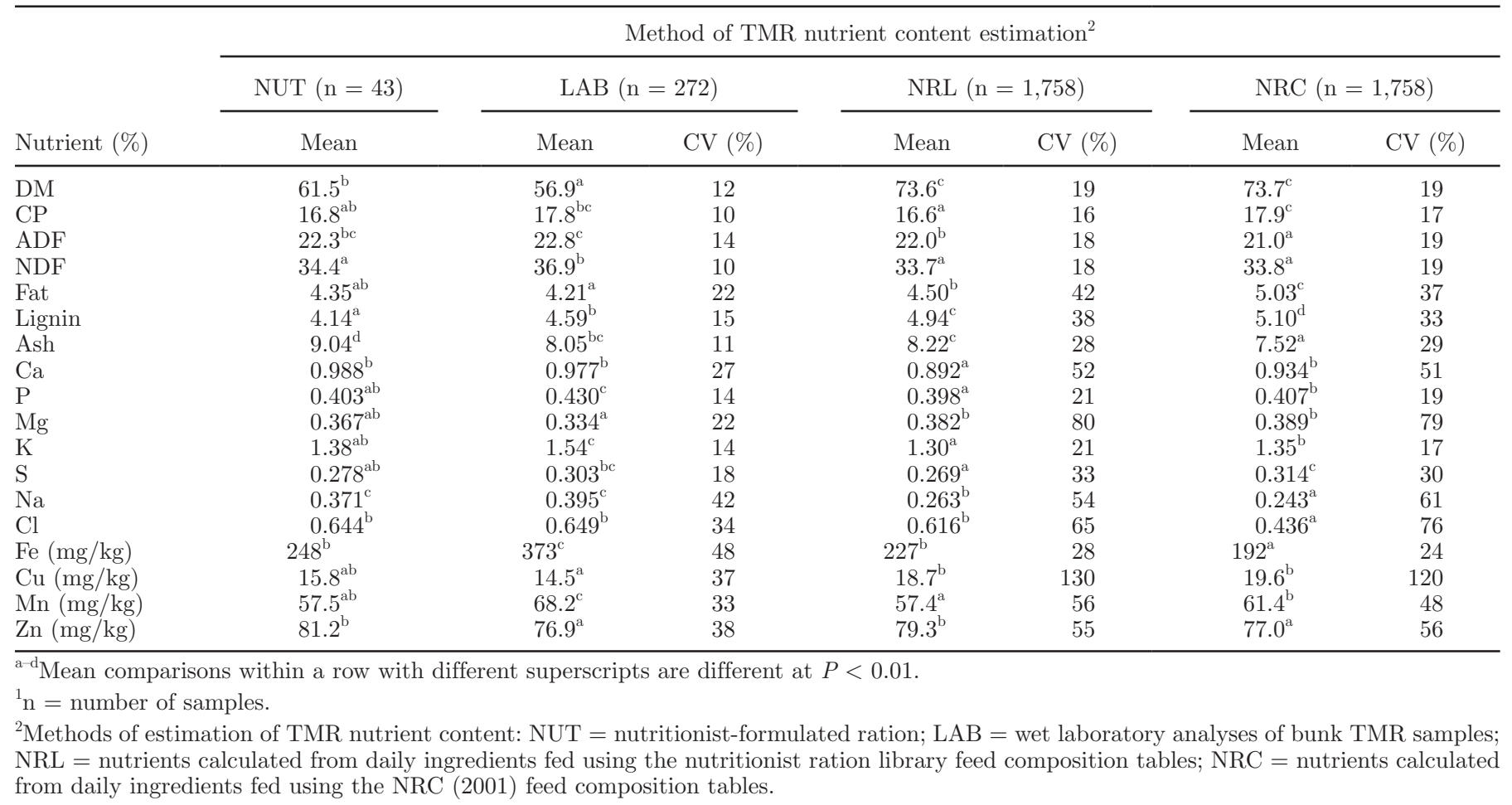



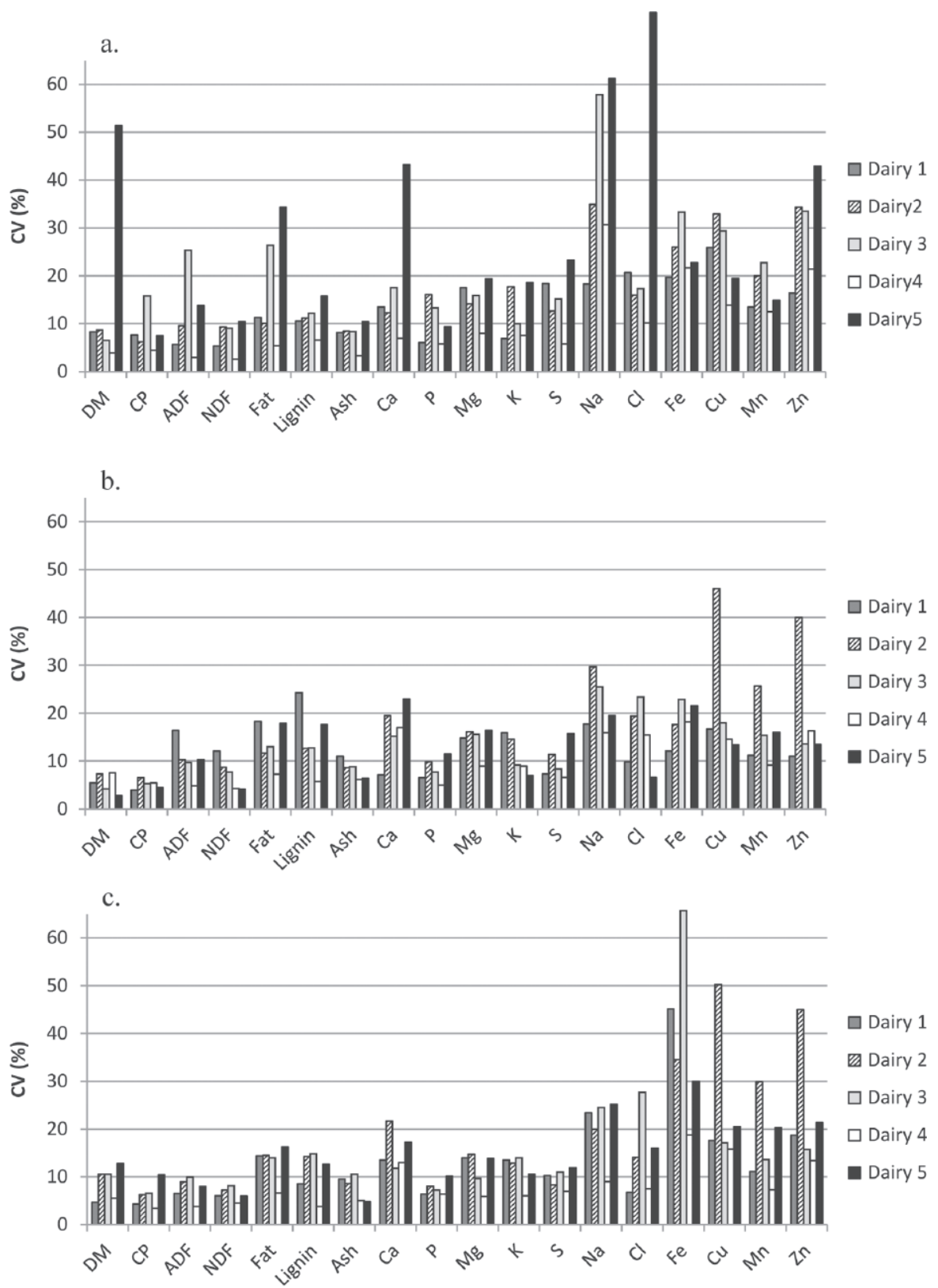

d.

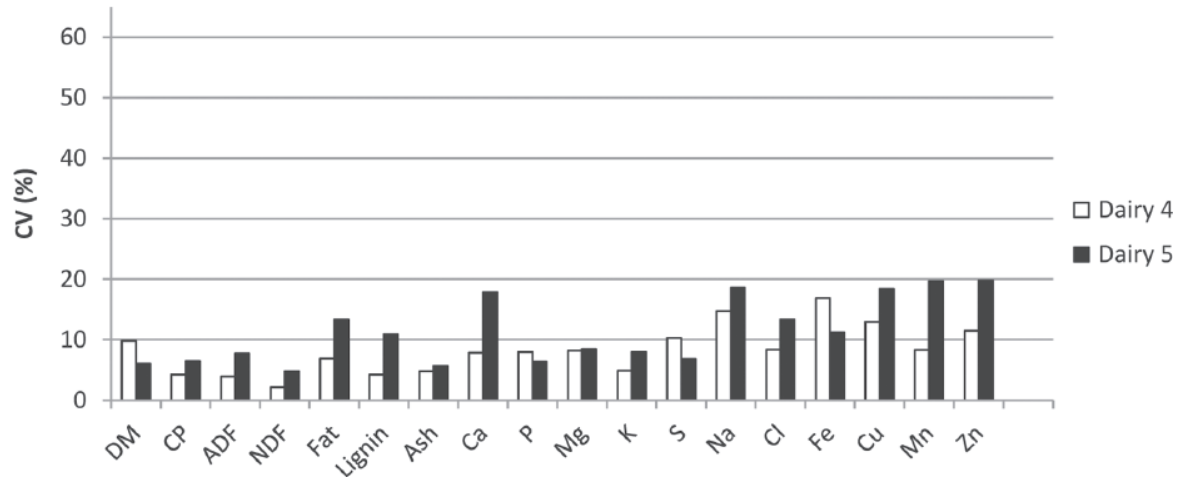

Figure 2. Coefficients of variation for TMR nutrients from weekly bunk samples analyzed by a laboratory for each of the 5 dairies from the (a) close-up pen, (b) fresh pen, (c) high-producing pen, and (d) low-producing pen. 
effect, analysis (NUT, LAB, NRL, and NRC) as a fixed effect, and pen as a repeated effect.

For objective 3 (to determine the effect of variability in nutrient supply on variability in milk and milk fat produced), nutrients (LAB) delivered to cows were compared with monthly pen milk variance. Weekly nutrient analyses were date matched to monthly milk tests so that only those nutrient contents of the TMR would be correlated with the current milk test. Milk protein was not included in the analyses because it was not measured on all of the dairies, very little variation was observed in milk protein production (Table 2; Figure 2), and all dairies were feeding excess protein (17.8\%, on average; Table 3) according to NRC (2001). Linear mixed models (Stata 12.0; StataCorp LP, College Station, TX) were used to estimate the variability in the outcome $(\mathrm{Y})$, with separate models for the outcomes test-day milk $(\mathrm{kg})$ and milk fat (\%). For each outcome's model, a categorical variable for the ith dairy pen was specified as a fixed effect, with $\mathrm{i}=1 \ldots 24$. In addition, fixed effects for moisture, CP, NDF, starch, oil, lignin, and ash were forced in the model. A random intercept for the jth cow $\left(u_{0 j}^{\text {cow }}\right)$ was cross-classified by nutrients. Cross-classification of cow by nutrient fed was specified by including a random intercept for each nutrient parameter, including moisture $\left(m_{0 k}^{\text {moisture }}\right), \mathrm{CP}$ $\left(c_{0 p}^{\mathrm{CP}}\right), \operatorname{NDF}\left(n_{0 q}^{\mathrm{NDF}}\right), \operatorname{starch}\left(s_{0 r}^{\text {starch }}\right), \operatorname{oil}\left(o_{0 t}^{\text {oil }}\right), \operatorname{lignin}\left(l_{0 w}^{\text {lignin }}\right)$, and $\operatorname{ash}\left(a_{0 x}^{\text {ash }}\right)$ (Goldstein, 1987). The random effects for cow, moisture, CP, NDF, starch, oil, lignin, and ash were assumed to be distributed univariate normal, with means 0 and variances $\sigma_{\text {cow }}^{2}, \sigma_{\text {moisture }}^{2}, \sigma_{\mathrm{CP}}^{2}, \sigma_{\mathrm{NDF}}^{2}, \sigma_{\text {starch }}^{2}$, $\sigma_{\text {oil }}^{2}, \sigma_{\text {lignin }}^{2}$, and $\sigma_{\text {ash }}^{2}$, respectively. Residual errors $e_{i j k p q r t w x}$ were assumed to be distributed as $\mathrm{N}\left(0, \sigma_{\text {residual }}^{2}\right)$. Quantile plots of model residuals and standardized residuals were evaluated for normality. In addition, the empirical
BLUP for dairy, pen, and nutrients were estimated and evaluated for normality. The variability in milk production partitioned by nutrient is summarized in Table 4 . The intraclass correlation coefficient (ICC) was estimated to quantify the correlation in milk yield across the range of a nutrient's values and hence attributable to that nutrient's variability. The ICC of a specific nutrient was estimated as the ratio of the sum of all other random effects to the sum of all random effects and the residual error. For example, the formula for the ICC for moisture is summarized in the following equation:

Moisture ICC $=$

$\frac{\sigma_{\text {cow }}^{2}+\sigma_{\mathrm{CP}}^{2}+\sigma_{\mathrm{NDF}}^{2}+\sigma_{\text {starch }}^{2}+\sigma_{\text {oil }}^{2}+\sigma_{\text {lignin }}^{2}+\sigma_{\text {ash }}^{2}}{\sigma_{\text {cow }}^{2}+\sigma_{\text {moisture }}^{2}+\sigma_{\mathrm{CP}}^{2}+\sigma_{\mathrm{NDF}}^{2}+\sigma_{\text {starch }}^{2}+\sigma_{\text {oil }}^{2}+\sigma_{\text {lignin }}^{2}+\sigma_{\text {ash }}^{2}+\sigma_{\text {residual }}^{2}}$.

A poor correlation (ICC) of a particular nutrient is indicative of its potentially important influence on variability in milk production. A good correlation presented as a larger ICC value is indicative of less variability in milk production attributed to that nutrient. Hence, a list of nutrients ranked in ascending order by ICC reflects the most influential nutrients on variability in milk production (Table 5). Variability in milk fat due to nutrients was similarly investigated using ICC.

\section{RESULTS AND DISCUSSION}

The 5 dairies represent a wide range of philosophies of feed management. For all pens on dairy 1, feeds, combinations of corn silage, alfalfa hay, and pellets are made by a commercial feed mill (commercial pellet). Dairies 2 and 5 mix their own premixes, which are then fed to several different pens (except the close-up pen for dairy 2) and dairies 3 and 4 use a combination of their own mixes and commercial pellets.

Table 4. Ratio of variability in random effects relative to total variability for milk volume, milk protein, and milk fat from linear mixed model partitioning of the variance in random effects ${ }^{1}$

\begin{tabular}{lccccccc}
\hline & \multicolumn{3}{c}{ Milk $(\mathrm{kg})$} & & \multicolumn{3}{c}{ Milk fat $(\%)$} \\
\cline { 2 - 3 } \cline { 7 - 8 } $\begin{array}{l}\text { Random } \\
\text { variable }\end{array}$ & $\mathrm{VE}$ & $\mathrm{SE}$ & Ratio $^{2}$ & & $\mathrm{VE}$ & $\mathrm{SE}$ & Ratio \\
\hline Cow & $<0.0001$ & $<0.0001$ & $<0.0001$ & & $<0.0001$ & $<0.0001$ & $<0.0001$ \\
Ash & $<0.0001$ & $<0.0001$ & $<0.0001$ & & $<0.0001$ & $<0.0001$ & $<0.0001$ \\
$\mathrm{NDF}$ & $<0.0001$ & $<0.0001$ & $<0.0001$ & & $<0.0001$ & $<0.0001$ & $<0.00029$ \\
Moisture & 0.00838 & 0.00086 & 0.00040 & & $<0.0001$ & $<0.0001$ & $<0.00066$ \\
Starch & 0.0366 & 0.0051 & 0.0018 & & 0.000154 & $<0.0001$ & 0.0011 \\
CP & 0.0570 & 0.0074 & 0.0027 & & 0.000196 & $<0.0001$ & 0.0014 \\
Fat & 0.294 & 0.085 & 0.014 & & 0.00236 & 0.00072 & 0.016 \\
Lignin & 1.04 & 0.090 & 0.050 & & 0.00761 & 0.00083 & 0.053 \\
\hline
\end{tabular}

${ }^{1}$ Variance estimate (VE), SE (SE of the VE), and ratio for residual error for milk $=19.4,0.21$, and 0.93 , respectively; VE, SE, and ratio for residual error for fat $=0.133,0.0016$, and 0.93 , respectively.

${ }^{2}$ Ratio of variable's variance to total variance. 
Table 5. Intraclass correlation coefficient (ICC) estimates for the correlation in milk volume produced attributable to each nutrient's variability ${ }^{1}$

\begin{tabular}{|c|c|c|c|c|c|c|c|c|}
\hline \multirow{3}{*}{$\begin{array}{l}\text { Random } \\
\text { effect }\end{array}$} & \multicolumn{4}{|c|}{ Milk (kg) } & \multicolumn{4}{|c|}{ Milk fat $(\%)$} \\
\hline & \multirow[b]{2}{*}{ ICC } & \multirow[b]{2}{*}{ SE } & \multicolumn{2}{|c|}{$95 \%$ CI } & \multirow[b]{2}{*}{ ICC } & \multirow[b]{2}{*}{ SE } & \multicolumn{2}{|c|}{$95 \%$ CI } \\
\hline & & & LB & UB & & & LB & UB \\
\hline Lignin & 0.0190 & 0.0039 & 0.011 & 0.027 & 0.0198 & 0.0048 & 0.010 & 0.029 \\
\hline Fat & 0.0546 & 0.0041 & 0.047 & 0.063 & 0.0563 & 0.0054 & 0.046 & 0.067 \\
\hline $\mathrm{CP}$ & 0.0659 & 0.0052 & 0.056 & 0.076 & 0.0713 & 0.0069 & 0.058 & 0.085 \\
\hline Starch & 0.0670 & 0.0051 & 0.057 & 0.077 & 0.0716 & 0.0068 & 0.058 & 0.085 \\
\hline Moisture & 0.0683 & 0.0051 & 0.058 & 0.078 & 0.0720 & 0.0067 & 0.059 & 0.085 \\
\hline NDF & 0.0687 & 0.0051 & 0.059 & 0.079 & 0.0724 & 0.0068 & 0.059 & 0.086 \\
\hline Ash & 0.0687 & 0.0051 & 0.059 & 0.079 & 0.0727 & 0.0067 & 0.060 & 0.086 \\
\hline
\end{tabular}

${ }^{1} \mathrm{SE}=\mathrm{SE}$ of the estimate; LB = lower bound; UB = upper bound.

\section{Descriptions of TMR Ingredients}

Although the 5 dairies represent TMR rations formulated by 4 nutritionists, many of the rations contain similar ingredients. All close-up rations contained 8 to $10 \mathrm{~kg}$ of corn silage and alfalfa hay DM/cow per day, 0.5 to $2 \mathrm{~kg}$ of corn $\mathrm{DM} /$ cow per day, and a premix/ mineral pellet. Three of the dairies also included wheat straw or oat hay at approximately $1 \mathrm{~kg}$ of $\mathrm{DM} /$ cow per day. Most of the dairies used a premix pellet from a commercial feed mill. Comparatively high coefficients of variation in nutrients for dairies 3 and 5 (Figure 2a) were probably due to mixing most of the ingredients in the close-up ration on farm (dairy 5) or adding ingredients (mineral supplements) that were not included in the commercial premix (dairy 3). From Stone (2008), variability in rations may contribute to variation in milk production and increases in metabolic diseases. Ration variation is reduced when feed mixes are purchased from a feed manufacturer with quality control procedures in place. The fresh cow and high-producing cow TMR rations were composed of corn silage, wheat silage, oat hay/wheat straw, alfalfa hay, and green chop (8 to14 $\mathrm{kg}$ of $\mathrm{DM} /$ cow per day), rolled corn (3 to $6 \mathrm{~kg}$ of DM/cow per day), almond hulls (1 to $3 \mathrm{~kg}$ of $\mathrm{DM} /$ cow per day), soybean hulls (approximately 1 $\mathrm{kg}$ of $\mathrm{DM} /$ cow per day), whole cottonseed (0.5 to 2 $\mathrm{kg}$ of $\mathrm{DM} /$ cow per day), canola (0.5 to $3 \mathrm{~kg}$ of $\mathrm{DM} /$ cow per day), dried distillers grains (1 to $3 \mathrm{~kg}$ of DM/ cow per day), wheat mill run (0.5 to $2.0 \mathrm{~kg}$ of DM/ cow per day), and premix and (or) pellets. Dairies 3 and 4 fed green chop alfalfa and dairies 2, 4, and 5 fed citrus pulp or cull fruit when available. Only dairies 4 and 5 fed a low-producing cow TMR that was similar in composition to the fresh and high-producing cow TMR, except rolled corn content was lower (2 to $3 \mathrm{~kg}$ of $\mathrm{DM} /$ cow per day).

\section{Variability in Nutrients Delivered to Cows and Milk Produced}

Overall, the most variation in nutrients was for the close-up TMR, followed by $\mathrm{Fe}, \mathrm{Cu}$, and $\mathrm{Zn}$ for the highproducing cow TMR (Figure 2c; dairies 1, 2, and 3) and $\mathrm{Na}, \mathrm{Cu}$, and $\mathrm{Zn}$ for the fresh cow TMR (Figure 2b; dairy 2). Variation was lowest in the low-producing cow TMR (Figure 2d). Because dairies 2 and 5 mix their own premix, it would be expected that their coefficients of variation would be highest and dairy 1 would be lowest. But what is surprising is that the high coefficient of variation was associated with the close-up TMR as opposed to the fresh and high-producing cow TMR. Some of the variability may have been due to contamination of the load by other diets or ingredients, because unlike other pens or TMR, close-up TMR are generally fed in 1 load. Microminerals $(\mathrm{Na}, \mathrm{Cl}, \mathrm{Fe}, \mathrm{Cu}$, $\mathrm{Mn}$, and $\mathrm{Zn}$ ) also had the highest coefficients of variation across the close-up, fresh, and high-producing cow diets, indicating that either TMR were not formulated for these minerals or supplements were inconsistently added or mixed. For the macronutrients, fat and lignin had higher coefficients of variation (10-30\%). Lignin was high probably because rations are not generally formulated for lignin. Fat content is a function of oilseed and bypass fat content, which are usually in the premix (mixed on the dairy or in the pellet), or addition of a sack to a load. Therefore, variability in fat content may represent variability in premix nutrient content or degree of mixing of a TMR.

Differences were observed in milk yield between the 5 dairies (Table 2). Dairy 1 had the highest production in the fresh pens and the lowest coefficients of variation for DIM and milk yield, whereas dairy 4 had the lowest milk production but the highest coefficients of variation for DIM and milk yield. For the high-producing 
pens, dairy 4 had the highest milk yield and lowest coefficients of variation and dairies 1 and 2 had the lowest milk yield and highest coefficients of variation. Milk fat production was different among dairies for the high-producing pen but not the fresh pen. Very little difference existed in milk protein production by any of the dairies for any of the pens. Differences existed in variability of nutrients supplied by dairies and pens, but milk yield may be the outcome most sensitive to nutrient variability. Although this comparison includes 2 types of variability (i.e., nutrient variability over days, with milk production variability among cows), because cows within the same pen have different nutrient requirements, variability in nutrient supply over several days should also affect variability in milk production among cows. Pecsok et al. (1992) developed equations for milk production and DMI to simulate how individual feeding versus group feeding influences feed efficiency and milk production. More groupings increased milk production, primarily due to less variation in cow nutrient requirements (i.e., feeding closer to the individual cow's nutrient requirements). Also, Bach et al. (2008) surveyed 47 herds in Spain to examine the relationship between management and herd performance. They observed a wide variation in average milk production per cow within a herd and day. Milk production ranged from 20.6 to $33.8 \mathrm{~kg} / \mathrm{d}$ and all herds were fed the same diet with a wide range in DMI per head per day of 16.2 to $24.8 \mathrm{~kg}$, which could be attributed to differences in management and housing conditions (i.e., about half the variation in milk production could not be attributed directly to nutrition and was probably due to differences in feed management). Therefore, daily variation in nutrients supplied to cows does affect milk yield and variation in milk production among cows but may not affect milk component production.

\section{Variability in Estimated TMR Nutrients}

Table 3 shows the comparison between TMR nutrient profiles from each source. As expected, NRL were not different from NUT nutrients for most of the nutrients because NUT TMR nutrients were formulated based on NRL values. Values for DM, lignin, ash, Ca, and Na were not the same as NUT values because NRL (and $\mathrm{NRC}$ and LAB) nutrients are affected by ingredient loading errors. The LAB nutrients were closer to NUT nutrients than NRC and had the smallest coefficients of variation, except for Fe. Therefore, LAB nutrients were used to compare nutrient variability to variability in milk production.

Most studies have focused on variability in nutrient content in individual TMR ingredients. Sniffen et al. (1993) described sources of nutrient variation from the individual cow requirements to feeding processes on the farm but focused on ingredient nutrient variation in ration formulation (St. Pierre and Harvey, 1986) instead of TMR nutrient variation. In addition, due to difficulties encountered in obtaining a representative sample of a TMR at the feed bunk, nutritionists often rely on the formulated TMR analyses predicted by the ration formulation package (NUT), TMR ingredient nutrient profiles from laboratory analyses (LAB), or reference analyses (NRC or NRL). Hristov et al. (2010) examined variability in feed and TMR NDF and CP among laboratories. They concluded most differences appeared to be due to differences in methods of analyses, although some were due to TMR composition (high-fat diets and level of starch content) and the difficulty encountered with TMR sampling. However, laboratory analysis was not a significant source of variability in the analyses of TMR. Endres and Espejo (2010) compared DM, $\mathrm{NDF}$, and $\mathrm{CP}$ content of the analyzed ration to the formulated ration from bunk samples. They found differences in NDF and CP contents between formulated and analyzed samples $(P<0.01)$ but not DM. Therefore, differences exist in laboratory analyses of nutrients and comparisons between delivered samples and formulated samples will exist due to differences in ingredient loading. From Weiss et al. (2012), it was concluded that variation in the TMR nutrient is a function of the square of the inclusion rate of each ingredient. But they observed that variation in nutrient content of the TMR also was less than variation observed in individual feed ingredients.

\section{Relationship Between TMR Nutrient Variability and Milk Production Variability}

To identify a marker or index of variability in feed management that could be included in ration formulation, the index should vary with variations in nutrients fed and affect variability in milk yield, milk fat percentage, or milk protein percentage. From data in Table 2, milk yield varies the most and, from Figure 2 and Table 3 , fat and lignin vary the most in macronutrients and $\mathrm{Fe}, \mathrm{Cu}$, and $\mathrm{Zn}$ vary the most of minerals in the TMR across all dairies and pens. To determine the potential effect of nutrient variation on variation in milk production, we partitioned the variance in test-day milk yield, milk fat, and milk protein by estimating the random effect (Table 4) and the ICC (Table 5) for each nutrient. Lignin, fat, and CP percentages were the greatest contributors to variability in test-day milk yield and milk fat percentage in analyses presented in both Tables 4 and 5 . For variability in milk protein percentage, the random effect of cow had a much greater contribution to milk protein variability, followed by fat and ash, 
indicating that TMR nutrient variability did not appear to affect variability in milk protein percentage. In addition, TMR contents were, on average, greater than $17.8 \%$ (Table 3), indicating that although TMR were formulated to a higher CP than required (16.8\%), variability in $\mathrm{CP}$ content of the TMR correlated with variability in milk yield and milk fat percentage but not milk protein percentage.

These results agree with results presented in Figure 2, where lignin and fat had higher coefficients of variation across pens and dairies. Values for ICC also confirm the correlation between variability in lignin, followed by fat with variability in milk production. Therefore, from this data, variability in lignin and fat appears to be a good index for variability in milk production and milk fat percentage due to feed management. Lignin content of the TMR is primarily from forages and some by-products and could represent variability in forage nutrient content due to feed management, whereas fat content may be more representative of minerals or premix - pellet or premix - concentrate portions of the diet, depending on whether the dairy mixes their own premix or purchases a premix. Variability in $\mathrm{CP}$ content is also important because variability in feed management may have large effects on manure nutrient concentrations, soil nutrient buildup, and environmental contamination (Powell et al., 2006). Lignin and fat are also not usually constrained in ration formulation with minimum constraints; therefore, other than their indirect effects on digestibility or diet quality, they are not considered to directly affect milk production. However, the relationship between variability in lignin, fat, and the variability in milk production could be used to introduce a penalty that represents variability in nutrients supplied to cows due to feed management for pens at individual dairies. Historical feeding records from feed management software programs such as FeedWatch or EZfeed could be used with monthly test data to quantify the relationship in variability in milk production with variability in lignin and fat content. In essence, diets would be formulated for higher milk production based on lignin and fat variability (ICC) of past TMR to increase nutrients supplied to cows. More research needs to be done to determine the cost or benefit associated with including feed management in ration formulation, the level of variability that would not affect ration formulation, and the production response of cows fed using this method.

\section{CONCLUSIONS}

Variability in nutrients delivered to cows is associated with variability in milk and milk fat produced and is a result of feed management practices. Variability in nutrients delivered is also greater than variability in TMR nutrients due to errors associated with laboratory analyses or reference values from feed lists. Therefore, as models of nutrient metabolism become more complex, it is important to understand limitations in the accuracy of supplying nutrients to cows on commercial dairies so that model predictions accurately reflect cow requirements. As feed management is an important factor in nutrient supply and milk production, it should be incorporated into ration formulation.

\section{REFERENCES}

AOAC International. 1999. Official Methods of Analysis. 16th ed. AOAC International, Gaithersburg, MD.

Bach, A., N. Valls, A. Solans, and T. Torrent. 2008. Associations between nondietary factors and dairy herd performance. J. Dairy Sci. 91:3259-3267.

Endres, M. I., and L. A. Espejo. 2010. Feeding management and characteristics of rations for high-producing dairy cows in freestall herds. J. Dairy Sci. 93:822-829.

Friggens, N., G. C. Emmans, S. Robertson, D. G. Chamberlain, C. T. Whittemore, and J. D. Oldham. 1995. The lactational responses of dairy cows to amount of feed and to the source of carbohydrate energy. J. Dairy Sci. 78:1734-1744.

Goldstein, H. 1987. Multilevel covariance component models. Biometrika 74:430-431.

Hristov, A. N., D. Mertens, S. Zaman, M. Vander Pol, and W. J. Price. 2010. Variability in feed and total mixed ration neutral detergent fiber and crude protein analyses among commercial laboratories. J. Dairy Sci. 93:5348-5362.

Huzzey, J. M., J. A. Fregonesi, M. A. G. von Keyserlingk, and D. M. Weary. 2013. Sampling behavior of dairy cattle: Effects of variation in dietary energy on behavior at the feed bunk. J. Dairy Sci. 96:247-256.

Kertz, A. F. 1998. Variability in delivery of nutrients to lactating dairy cows. J. Dairy Sci. 81:3075-3084.

NRC. 1989. Nutrient Requirements of Dairy Cattle. 6th rev. ed. Update. Natl. Acad. Press, Washington, DC.

NRC. 2001. Nutrient Requirements of Dairy Cattle. 7th rev. ed. Natl. Acad. Press, Washington, DC.

Pecsok, S. R., M. L. McGilliard, and R. E. James. 1992. Estimating production benefits through simulation of group and individual feeding of dairy cows. J. Dairy Sci. 75:1604-1615.

Powell, J. M., D. B. Jackson-Smith, D. F. McCrory, H. Saam, and M. Mariola. 2006. Validation of feed and manure data collected on Wisconsin dairy farms. J. Dairy Sci. 89:2268-2278.

Sniffen, C. J., R. W. Beverly, C. S. Mooney, M. B. Roe, and A. L. Skidmore. 1993. Nutrient requirements versus supply in the dairy cow: Strategies to account for variability. J. Dairy Sci. 76:3160-3178.

St. Pierre, N. R., and W. R. Harvey. 1986. Incorporation of uncertainty in composition of feedstuffs into least-cost ration models. 1. Single chance constrained programming. J. Dairy Sci. 69:3051-3062.

Stone, B. 2008. Reducing the variation between formulated and consumed rations. WCDS Adv. in Dairy Technol. 20:145-162.

Weiss, W. P., D. Shoemaker, L. McBeth, P. Yoder, and N. R. StPierre. 2012. Within farm variation in nutrient composition of feeds. Pages 103-117 in Proc. Tri-State Dairy Nutrition Conference, Fort Wayne, IN. The Ohio State University, Columbus. 
APPENDIX

Table A1. Average and SD of ration ingredients delivered to close-up pens at all 5 dairies during data collection periods ${ }^{1}$

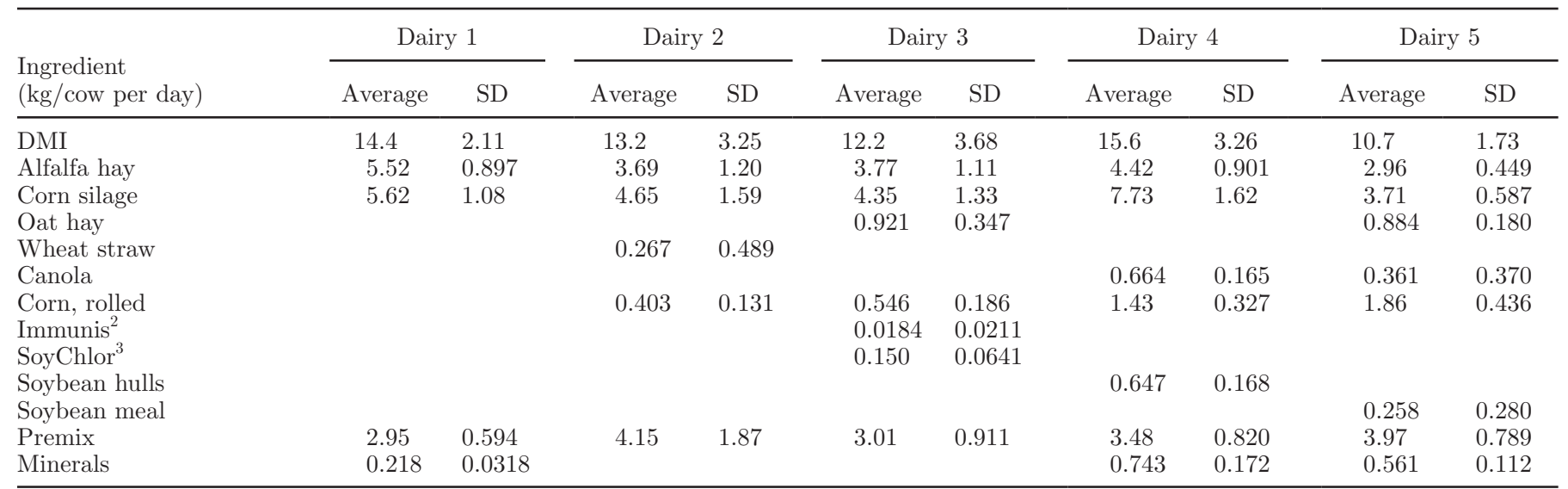

${ }^{1}$ Ingredients with SD are loaded individually into the mixed wagon. Ingredients present in small amounts are not listed individually in the table and are part of the premix or minerals.

${ }^{2}$ Enz-A-Bac, Twin Falls, ID.

${ }^{3}$ West Central Soy, Ralston, IA.

Table A2. Average and SD of ration ingredients delivered to fresh cow pens at all 5 dairies during data collection periods ${ }^{1}$

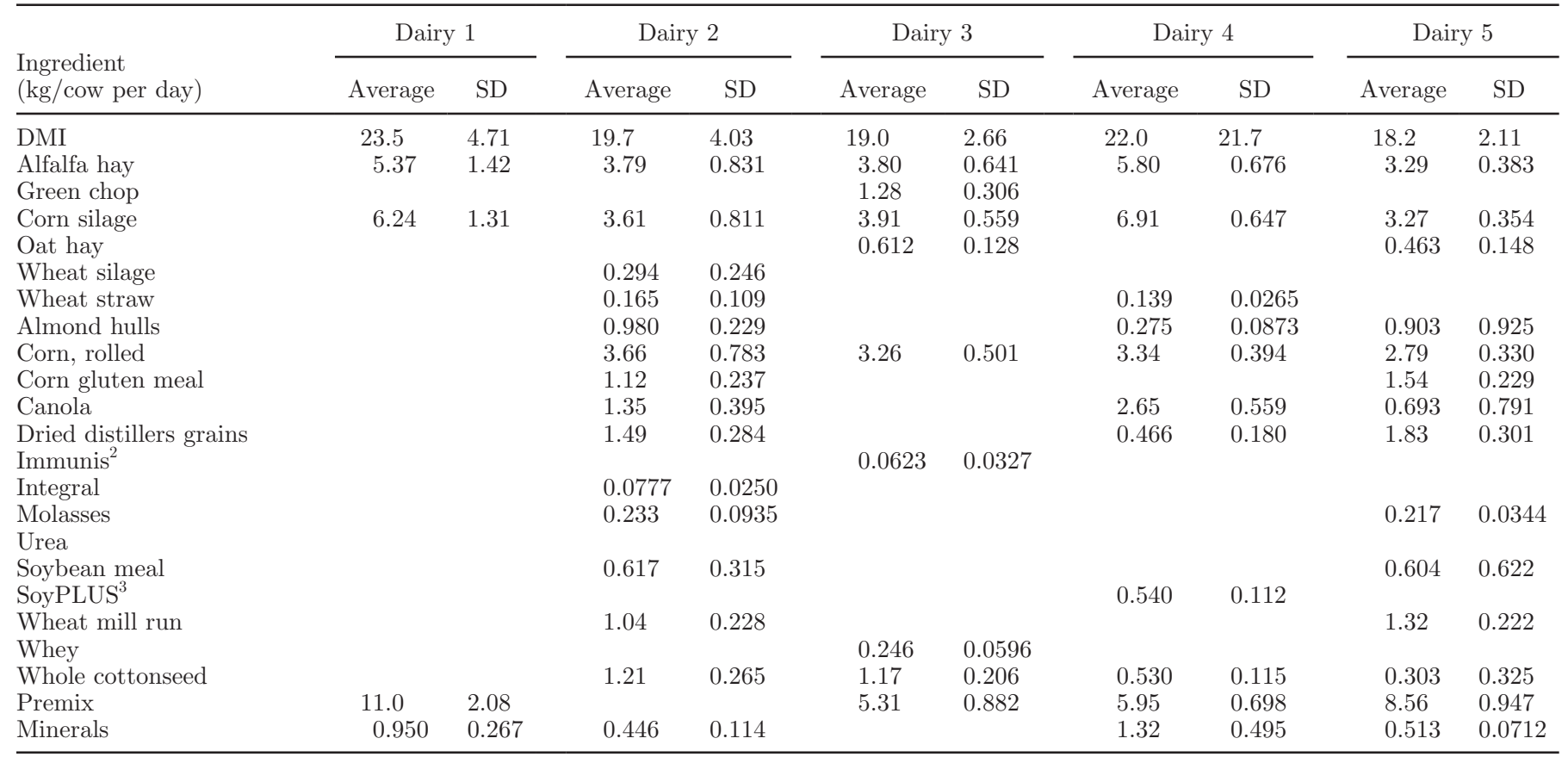

${ }^{1}$ Ingredients with SD are loaded individually into the mixed wagon. Ingredients present in small amounts are not listed individually in the table and are part of the premix or minerals.

${ }^{2}$ Enz-A-Bac, Twin Falls, ID.

${ }^{3}$ West Central Soy, Ralston, IA. 
Table A3. Average and SD of ration ingredients delivered to high-producing cow pens at all 5 dairies during data collection periods ${ }^{1}$

\begin{tabular}{|c|c|c|c|c|c|c|c|c|c|c|}
\hline $\begin{array}{l}\text { Ingredient } \\
\text { (kg/cow per day) }\end{array}$ & \multicolumn{2}{|c|}{ Dairy 1} & \multicolumn{2}{|c|}{ Dairy 2} & \multicolumn{2}{|c|}{ Dairy 3} & \multicolumn{2}{|c|}{ Dairy 4} & \multicolumn{2}{|c|}{ Dairy 5} \\
\hline DMI & 25.7 & 2.93 & 25.5 & 2.84 & 27.3 & 9.77 & 26.7 & 4.12 & 26.0 & 2.57 \\
\hline Green chop & & & & & 2.54 & 1.47 & 1.07 & 0.397 & & \\
\hline Corn silage & 6.90 & 0.831 & 4.25 & 0.672 & 6.26 & 1.73 & 5.41 & 0.989 & & \\
\hline Earlage & & & & & 0.428 & 0.756 & & & & \\
\hline Wheat straw & & & & & & & 0.120 & 0.0997 & & \\
\hline Almond hulls & & & 1.88 & 0.245 & 2.53 & 1.02 & 0.353 & 0.467 & 1.89 & 1.84 \\
\hline Canola & & & 1.94 & 0.346 & & & 1.11 & 1.46 & 0.896 & 0.966 \\
\hline Corn gluten meal & & & 1.48 & 0.173 & & & & & 2.01 & 0.235 \\
\hline Corn, ground & & & & & 1.34 & 0.134 & & & & \\
\hline Corn, rolled & & & 4.61 & 0.546 & 3.28 & 1.05 & 5.21 & 1.08 & 4.42 & 0.497 \\
\hline Dried distillers grains & & & 1.75 & 0.209 & & & 0.447 & 0.590 & 2.36 & 0.266 \\
\hline Soybean meal & & & 0.667 & 0.324 & & & & & 0.743 & 0.749 \\
\hline SoyPLUS $^{4}$ & & & & & & & 0.360 & 0.475 & & \\
\hline Wheat mill run & & & 1.40 & 0.182 & & & & & 1.71 & 0.226 \\
\hline Whey & & & & & 0.461 & 0.165 & & & & \\
\hline Whole cottonseed & & & 1.64 & 0.218 & 1.58 & 0.441 & 0.351 & 0.464 & 0.721 & 0.712 \\
\hline Premix & 12.0 & 1.38 & & & 6.07 & 1.73 & 8.50 & 1.57 & 11.3 & 2.19 \\
\hline Minerals & 1.06 & 0.419 & 0.633 & 0.111 & & & 0.513 & 0.688 & 0.664 & 0.0765 \\
\hline
\end{tabular}

${ }^{1}$ Ingredients with SD are loaded individually into the mixed wagon. Ingredients present in small amounts are not listed individually in the table and are part of the premix or minerals.

${ }^{2}$ Enz-A-Bac, Twin Falls, ID.

${ }^{3}$ H. J. Baker \& Bro. Inc., Westport, CT.

${ }^{4}$ West Central Soy, Ralston, IA.

Table A4. Average and SD of ration ingredients delivered to low-producing cow pens at dairies 4 and 5 during data collection periods ${ }^{1}$

\begin{tabular}{lccccc}
\hline & \multicolumn{2}{c}{ Dairy 4} & & \multicolumn{2}{c}{ Dairy 5} \\
\cline { 2 - 3 } \cline { 5 - 5 } $\begin{array}{l}\text { Ingredient } \\
\text { (kg/cow per day) }\end{array}$ & Average & SD & & Average & SD \\
\hline DMI & 28.3 & 2.02 & & 21.4 & 3.65 \\
Alfalfa hay & 3.10 & 0.897 & & 3.25 & 0.549 \\
Green chop & 1.18 & 0.349 & & & 3.77 \\
Corn silage & 5.96 & 0.723 & & 0.675 \\
Oat hay & 0.256 & 0.0419 & & 0.493 & 0.138 \\
Wheat silage & 3.11 & 0.251 & & \\
Wheat straw & 0.334 & 0.665 & & & \\
Almond hulls & 1.52 & 0.500 & & 2.02 & 0.521 \\
Canola & 1.92 & 0.522 & & 0.779 & 0.854 \\
Corn gluten meal & 2.50 & 0.636 & & 1.69 & 0.284 \\
Corn, rolled & 3.29 & 0.300 & & 3.42 & 0.603 \\
Dried distillers grains & 1.79 & 0.274 & & 1.99 & 0.346 \\
Fruit & 0.626 & 0.138 & & 0.0229 & 0.0975 \\
Megalac & & & & 0.206 & 0.100 \\
Molasses & 0.0702 & 0.0194 & & 0.236 & 0.0410 \\
Wheat mill run & 1.02 & 0.157 & & 1.45 & 0.259 \\
Whole cottonseed & 0.777 & 0.131 & & 0.330 & 0.355 \\
Soybean meal & & & 0.615 & 0.639 \\
Mineral & 0.623 & 0.175 & & 0.558 & 0.0985 \\
\hline
\end{tabular}

${ }^{1}$ Ingredients with SD are loaded individually into the mixed wagon. Ingredients present in small amounts are not listed individually in the table and are part of the premix or minerals.

${ }^{2}$ Church \& Dwight Co. Inc., Ewing, NJ. 